\title{
Flipped Classroom Teaching Based on Massive Open Online Course: A New Criminology Teaching Method
}

\author{
Aijiao Liu \\ The Department of Law \\ Yunnan Police Officer Academy \\ Kunming City Yunnan Province, P.R.C.
}

\author{
Ting Zhao* \\ The Department of General Education \\ Yunnan University of Business Management \\ Kunming City, Yunnan province, P.R.C.
}

\begin{abstract}
Criminology is an important discipline that explains crimes from the perspective of society and is used to solve crime problems fundamentally. However, at present criminology course is facing a plight in which teachers are not willing to teach and students are reluctant to learn. There are several reasons explaining why plight occurs. Firstly, the importance of the course has not been totally understood. Secondly, the empirical teaching method cannot take effect in the traditional teaching mode. Moreover, students may be discouraged from the course because criminology as a discipline of social science is so difficult for most of them. Therefore, it is necessary to guarantee the needed conditions for teaching and scientific research by enhancing the discipline status of criminology. It is also essential to explore new teaching methods from teachers and students and promote the comprehensive development of students' learning of criminology by taking advantage of high technology.
\end{abstract}

Keywords-criminology; massive open online course; flipped classroom; teaching methods

\section{INTRODUCTION}

Based on Massive Open Online Course (hereafter referred to as MOOCs), flipped classroom changes the roles of teachers and students in traditional teaching and rearranges in-class time through the flipped arrangement of knowledge imparts and knowledge internalization, realizing the innovation of traditional teaching mode. It reverses the teaching organization, teaching implementation and teaching methods from the aspects of the status and effects of teachers, the way students receive knowledge, the teaching organization, the way of imparting knowledge, the medium and means of acquiring knowledge and the method of teaching effect evaluation. Criminology, as a course set up by many professional colleges and universities, bears its abstract theoretical property. If we can break the traditional teaching mode and utilize information and communication technology and platforms in the age of "Internet Plus" to construct theories of the flipped classroom which are suitable for theory teaching, it is not only effective in criminology teaching, but also meaningful in innovation of theory courses teaching in colleges and universities.

This paper is the staged achievement of university-level general projects of Yunnan Police Officer Academy "the Application of Flipped Classroom Teaching Mode Based on Massive Open Online Course into Criminology Teaching in Public Security Colleges" in 2018.

\section{The CONNOTATION ON FliPPED ClassRoom TEACHING THEORY BASED ON MOOCS}

\section{A. $M O O C s$}

MOOCs have swept the global education sector and become a milestone in the development of education since its emergence in 2012. At present, MOOCs website for basic education in China is launched by C20 (It is a coalition formed by more than 20 well-known schools in China which includes high schools, middle schools and primary schools) led by East China Normal University. Then main courses include a large number of open online video courses of primary and secondary schools. Although these online video courses are enough for students to study during their fragmented time, the courses have not formed a rigorous teaching system yet. Students cannot study a course on the website systematically, thus MOOCs cannot provide enough support for school teaching and MOOCs have not yet been able to form an effective impact on the traditional in-class teaching mode. MOOCs in China still need further development and there is still a lot of room for improvement, especially in the curriculum system, sense of rhythm, unified style of teachers and other aspects.

\section{B. Flipped Classroom}

At present, there are still controversies about the specific interpretation and definition of the flipped classroom in the education field at home and abroad, which also shows different countries maintain different endeavor directions in education development mode in the future. American New Media Consortium defined in Horizon Report that flipped classroom is students watch video lectures, video courses and electronic books to realize self-study during their extra-curricular time; Based on project or problems, students study together with the teachers and classmates to achieve the methods of solving practical problems and gain a deeper understanding of knowledge. The definition of flipped classroom given by Chinese educational experts is that students watch teachers' lectures in videos in extracurricular time. Then the teacher and students communicate with each other in class and finish homework. In contrast, the definition of flipped classroom given by the American New Media Consortium is more suitable for the research content of this 
paper and more in line with the project of flipped classrooms based on MOOCs.

\section{The Correlation between MOOCs and Flipped Classroom}

MOOCs are web-based courses with freedom and openness. MOOCs are open to all and most teachers on the platform are well-known professors from home and abroad. The materials from these online course platforms are high-quality teaching resources, which realize the sharing of high-quality educational resources. The flipped classroom takes advantage of teaching resources and teaching methods such as micro-class and MOOCs, and combines with video teaching to achieve teaching results. The flipped classroom can focus on cultivating students' self-study ability and stimulate students' subjective initiative to the maximum degree. Moreover, flipped classroom changes the traditional teaching thought in the past and reverses passive learning to active learning, transforming teacher-led learning mode and promoting the development of learning mode based on students' cognitive level. Besides, it reverses the single classroom teaching organization mode and builds a mixed online and offline teaching mode.

\section{The CurRent Situation And PROBlems of Criminology TEACHING In Public SECURITy COLlegeS}

Taking Yunnan Police Officer Academy where the author works as an example, the School of Law in the academy sets up several majors, including basic law, administrative law, criminal law and civil and commercial law. Criminology, as a sub-discipline of the basic law, the course hours depend on the majors of students who major in law have two-course hours every week while students who do not major in law have three-course hours per week. The School of Law has been applying for criminology as a major, but it has not been approved. Thus, only two professional teachers are needed for criminology courses in the whole academy.

\section{A. Teaching Forms}

Many criminology teachers teach criminal law at the same time in my academy. For a long time, criminal law is the core of professional courses while criminology is just an optional course. These teachers who teach criminal law courses at the same time are inclined to combine the teaching mode of criminal law with the teaching mode of criminology, dividing criminology into general theory and sub-theory and focusing on the theoretical description of the phenomena, causes and countermeasures of crimes. In the middle of the semester, teachers start to teach the so-called sub-theory during which teachers will explain specific types of crimes, which cannot leave deep impressions of criminology on students and cannot show features and advantages of criminology itself. Many criminology teachers who also undertake criminal law courses are apt to teach criminology with the mode of theory plus case which is usually used in criminal law courses, emphasizing crimes and penalties. Undoubtedly, the teaching forms of criminology courses fall into the cycle of criminal law courses. These are misconceptions about criminology teaching forms.

\section{B. The Setting of Curricula}

In fact, criminology is a highly comprehensive discipline. Criminology is neither subordinate to criminal law nor sociology. It is an independent subject parallel to sociology, economics, law and anthropology, but it is inextricably linked to these disciplines. However, the academy where the author works open criminal law in the first year of college and criminology in the second year, which fully embodies the discipline orientation which attaches greater importance to the criminal law than criminology. As scholars have said, criminology, which is at the upper stream of the "academic chain" of criminal science, provides knowledge, methods and intellectual thoughts for the development and improvement of criminal law. Nevertheless, the School of Law opens criminology course after the criminal law course. Criminology is by no means a subsidiary of criminal law and is not an optional subject.

\section{EXPLORATION OF REFORM IN CRIMINOLOGY TEACHING METHODS WITH FLIPPED CLASSROOM BASED ON MOOCS}

To change the current plight of criminology teaching, it is a must to bring high technology into classroom, change traditional teaching concepts, enrich teaching methods, enhance the status of students in the teaching process, make the interactive development of teaching and learning, and guide students' learning in accordance with the situation instead of "violence blocking".

\section{A. Improving the Subject Status of Criminology and Ensure the Necessary Conditions for Teaching and Scientific Research}

In the current discipline system, criminology should be adjusted from an optional course to a compulsory course. In terms of assessment method, it can be changed from inspection to examination to promote students' learning enthusiasm through external pressure. On the basis of improving the status of this discipline, the necessary conditions for the course teaching and scientific research should be guaranteed. In terms of teaching, criminology is different from other law disciplines. Without the study of empirical research methods, it is impossible to grasp the essence of the course. Therefore, colleges and universities should make the course teaching truly go into society through the guarantee of funds, facilities and security. Only by going into society, can students realize the importance of the course and change the traditional understanding about the course. And only by studying realistic cases can students' integrate understanding of the crime phenomena be enhanced and make the criminology learning more intuitive, more comprehensive and more practical. Criminology learning should not be confined in the classroom but expanded to a broader vision to put forward practical and feasible measures, which can not only make criminology learning interesting and appealing, but also arouse students' enthusiasm to learn without any external motivation. In terms of scientific research, schools should guarantee the investment of scientific research funds, encourage teachers to keep pace with the times and make bold innovations. If teaching has a scientific research foundation, it will have a foundation for further development and exploration. 


\section{B. Teachers' Practical Activities}

\section{1) Choosing Teaching Content and Designing Teaching} Activities

If the flipped classroom is applied in criminology teaching, teachers should decompose teaching content, divide the teaching content into sub-units, and refine teaching sub-tasks according to the course content and teaching targets. Then teachers should choose some operable contents to improve students' ability to utilize criminology theories to analyze and study criminal issues. In addition, these operable contents which are highly consistent with the content of teaching and curriculum contribute to the practice of flipped classrooms. The practical forms that can be adopted are as follows.

The first reverse is in the knowledge imparting phase. For basic historical facts in the course content, teachers can ask competent students to give a lecture on the premise of limited tasks. Teachers can provide students with relevant referential materials and extensive learning materials, so that students can experience the process of course preparation and teaching. These processes complete the reverse of roles in flipped classroom. The second reverse is in the knowledge internalization phase. According to the practical mode and operational ideas of flipped classroom, the internalization and grasp of knowledge and the improvement of ability can be realized by task-driven learning, interaction and exploration before and in class.

\section{2) Preparation for Teaching Materials}

Teaching materials are essential prerequisite for flipped classroom. Teachers should make or provide corresponding teaching materials according to the selected teaching contents and students' learning ability to ensure that students can complete the learning tasks. These teaching materials should not only meet the needs of students to complete the tasks, but also have certain openness and depth to promote students' multi-dimensional and multi-directional thinking on the tasks.

\section{3) Paying Attention to Students' Conditions}

Since students' learning activities after class cannot supervised by teachers, in order to ensure the effective implementation of flipped classroom, teachers should keep an eye on students' learning conditions and the completion of tasks after class in time. The realization of this phase needs the support of information platforms and information technology. Teachers can grasp students' dynamics in the way of random interview through various information exchange and interaction platforms.

\section{4) Instructions and Guidance on In-class Activities}

In-class activities of flipped classroom are not only the extension of students' independent learning, but also the examination and summary of students' learning results. As for the problems generated by students in the independent learning phase, teachers can solve the problems in class by means of discussion, debate, mutual answers and Q\&A. Meanwhile, teachers should pay attention to the dynamics of students. At the appropriate time, teachers should intervene to instruct students and adjust the atmosphere, guiding students to think, discuss, analyze problems in accordance with the thinking of teaching design, and achieving the designed teaching tasks and objectives in the flipped classroom.

\section{Students' Practical Activities}

\section{1) Defining Tasks and Studying independently}

As the active subject of the flipped classroom, students should first understand and comprehend the learning tasks assigned by the teacher, and then study the learning materials provided by the teacher with tasks. If teachers do not give clear requirements for implementation modes, students can choose to learn alone, learn with a partner, and learn in groups. Its core and purpose are to accumulate and grasp knowledge, improve the ability of self-management and enhance the ability of cooperation and interpersonal communication.

\section{2) Generating Problems and Seeking Solutions}

The process of students' self-study with tasks before class is not only the process of task completion and problem-solving, but also the process of generating new problems. With the accumulation of students' knowledge, the continuous improvement of their ability and the introduction of extended knowledge, students can change their way of thinking, broaden their thinking scope and expand their thinking space. They can have newer, deeper and broader thoughts on the learning tasks assigned by teachers, and at the same time, they may generate extra questions about the same problem. Some of these problems can be solved through in-depth study and careful exploration, while others can be solved by asking for help from teachers, other students or experts.

\section{3) Multi-directional Interaction and Problem-Solving}

In-class learning of flipped classrooms is to solve the problems generated by students before class, which can be solved through multi-dimensional, multi-directional interaction among teachers and students. For example, in order to solve problems, students can interact with one another, groups can interact with one another, students can interact with teachers, and group representatives can interact with teachers. In the interactions, teachers should only solve problems that cannot be solved by multilateral discussion and exploration and leave more problems to students to stimulate more interaction among students, which contributes to the cultivation of students' ability to explore. In case those teachers encounter questions that they cannot answer, the teacher should explain to students and ask experts to solve after class.

\section{SUMMARY}

As one of the representative courses of theoretical teaching in public security colleges, the criminology course adopts advanced teaching concepts and methods in its teaching, which will undoubtedly bring vitality to the course. However, when advanced teaching methods are adopted, especially those which are suitable for courses with abstract theories, it is necessary to select teaching contents and teaching units (or sub-units) to ensure the effectiveness of teaching and the integrity of the curriculum system. On the premise of qualified practical conditions, the practice of flipped classroom requires teachers and students to clarify their practical tasks in each 
[2] Chen Zichao, Jiang Jiafu, "The Exploration and Practice of the Flipped Classroom in University Courses”, Modern Educational Technology,

phase with tasks as the core, students as leaders and teachers as instructors.

\section{REFERENCES}

[1] Li Hailong, Deng, Mingjie, Liang Cunliang, "Design and Application of Task-based Flipped Classroom Teaching Model”, Modern Educational Technology, Vol. 23, No.9, 2013. Vol.24, No.12, 2014.

[3] Li Xiao, "Application and Thinking of Flipped Classroom Teaching Model in Colleges and Universities”, Intelligence, November 2014.

[4] Zeng Xiangguang, "Research on the Application of Task-driven Teaching Method in Flipped Classroom Practice”, CHINA ADULT EDUCATION, July 2014.

[5] Han Lizhen, "The Bottleneck and Direction Choice of Flipped Classroom Development in China”, Journal of Jiangsu Radio \& Television University, Vol.24, No2, 2013, pp.24-41. 